Trakia Journal of Sciences, Vol. 17, Suppl. 1, pp 488-495, 2019

Copyright (C) 2019 Trakia University

Available online at:

ISSN 1313-7069 (print)

http://www.uni-sz.bg

ISSN 1313-3551 (online)

doi:10.15547/tjs.2019.s.01.079

\title{
SOCIAL ENTERPRISES` POSITION IN REGIONAL SUSTAINABLE DEVELOPMENT
}

\author{
H. Blagoycheva* \\ Finance Department, University of Economics - Varna, Bulgaria
}

\begin{abstract}
The purpose of this article is to investigate the possibilities of integrating the activity of social enterprises into the regional sustainable development goals. Traditionally, from an economic point of view, the social enterprises are not a dominant form of business management that contributes to the regional development. But in the article, they are seen as major players within the social economy that can facilitate a sustainable local and regional development. The benefits of the social enterprises are that they manage to combine economic, environmental and social goals in "one basket", thus helping to meet diverse local and regional needs. Based on studied academic discussions and the European Union's experience in building different approaches to developing social entrepreneurship, attempts are being made to address the challenges facing social enterprises at the regional level. Various opportunities are also considered to overcome these challenges.
\end{abstract}

Key words: social entrepreneurship, social capital, sustainability of the regions, sustainable social enterprise.

\section{INTRODUCTION}

As early as in 1987 Brundtland stated that sustainable development should meet present needs without compromising the abilities of the next generations to meet their own needs (1). This suggests numerous responsibilities for the present generations. In their activities they should consider a number of challenges related to pursuing economic growth without ignoring its social and environmental implications. Sustainable development demands that we not leave to our descendants the costs of overcoming social or environmental problems and thus limit the choices of future generations. Therefore the strive for sustainable development calls for taking a wide range of actions to ensure social changes, all of them including various and

\footnotetext{
"Correspondence to: Hristina Blagoycheva, Finance Department, University of Economics - Varna, Varna, Bulgaria, e-mail: hrblagoycheva@uevarna.bg
}

strongly interrelated aspects of complicated and multi-dimensional character (2).

The growing awareness of this need has led, over the last few years, to a gradual convergence of the concepts of sustainable development and those of the social economy. A point has been reached where it can be assumed that social economy, apart from having already proved its strength in effectively aiding the solution of emerging economic problems, is coming forward as a necessary factor for a stable and sustainable growth (3). Social enterprises, within the framework of their entrepreneurial activity, have established themselves as the key actors in social economy which are to respond to the dynamics of change.

Traditionally, from an economic point of view, social enterprises have not been the dominant form of business management to contribute to regional growth. But within the framework of social economy, these are characterized by a 
BLAGOICHEVA $H$.

number of prerequisites for sustainable regional development through creating jobs, satisfying certain regional social needs and organizing collective activities which bring about regional cooperation and joint solidarity. Social enterprises are an incubator for social innovations which are usually aimed at meeting local or regional needs.

Therefore, the purpose of this article is to bring forward the responsibility assumed by social enterprises to sustainable regional development, the problems these businesses face and the possibilities that exist for supporting their activities.

\section{THE CONVERGENCE BETWEEN SUSTAINABLE REGIONAL DEVELOPMENT AND SOCIAL ENTREPRENEURSHIP}

The process of sustainable regional development involves many stakeholders acting in aid of achieving a common goal that contains three basic points: economy, environment and society. Those three concepts interact and should therefore be viewed within the framework of systemic relationships (4). From an economic perspective sustainability is associated with supplying goods and services to the population with a minimal impact on the environment. From an environmental standpoint sustainability requires the preservation of biological and natural diversity as well as reducing the waste of natural resources. From the point of view of society, sustainability aims to preserve universal values such as freedom, peace and justice (5). Achieving those three ambitious goals will ensure stability and sustainability for the society as a whole, in all of its aspects.

For a long period of time the idea of regional development focused mostly on economic growth, with market-orientated strategies aimed at improving economic efficiency (6). Historically viewed, economic problems prevail - providing employment, raising productivity and income levels in the region $(7,8)$. Later on this too narrow focus was criticized on the grounds of the fact that strategies of development were directed depending on both social requirements and political motives (8).

Talking about local development we ought not to mean a small location, but rather the development of an entire geographical and culturally located region. Obviously we shall have to examine a territory where certain historically determined relationships function, and mainly those of common territorial background and coexistence. Within the said frameworks another determining factor is also the relationships between the various local participants, who live, work and interact with the environment. Sustainable regional development, along with its economic objectives, aims at an overall improvement of the quality of life in the respective territory. It is important, therefore, to have good knowledge of the natural, technical economic, institutional and socio-cultural potential of the territory, so that the needs of the various participants are met in a sustainable manner (5).

A present look into the current state of European regions and those across the world shows that in historical retrospect there are no established, recurring models that could, by means of purely economic instruments, assist a more even economic development, accompanied by social justice for today's generations as well as the next ones. Therefore, we once again address Brundtland's definition as applied to sustainable regional development, and expand it into a breakdown of three distinctive groups of activities aimed at: satisfying basic human needs; creating communities that establish norms, rights, and collaborative behaviour as a prerequisite for participating in social and economic development; and translating the more abstract needs of future generations into action today (9, p. 7). To achieve regional sustainability it is already necessary to pursue goals such as environment protection, overcoming social exclusion and raising the overall standards of living in the community. Those three directions, in addition to the recognition of cultural diversity, feature frequently in the new expanded definitions of sustainable regional development $(8,10)$.

What, then, should be the characteristics of participants who adopt a certain behavior and follow strategies for achieving sustainable development? We cannot but conclude that theirs is an extremely heterogeneous group (11). In the cases described the nature of participants appears to be rather diverse. A study (12) characterizes them as individual entrepreneurs who find new and effective ways of creating goods, services or structures which directly 
serve or allow others to take care of social needs that have to be satisfied in order for sustainable development to be achieved.

It is precisely the activity of social economy that aims to encourage the social and economic wellbeing of local communities in order to create a more inclusive and more democratic society. One of the major prerogatives of social economy and social enterprises in particular is to tackle urgent problems and find solutions to specific emerging needs, revive social connections in the particular region, as well as those orientated towards sustainable regional development. The paths of social entrepreneurship and sustainable development
BLAGOICHEVA $H$.

cross (11). Under social economy a social enterprise can provide an alternative solution concerning the flaws appearing in marketorientated economy and can help towards sustainability of regional development in several aspects. The social enterprise is characterized by an innovative business approach that is able to provide financial sustainability of the business itself and the region, on the one hand, and on the other - providing social support for certain groups of citizens and ecological value for society. Table 1 presents a systematized picture of the benefits from social enterprises for the regional development.

Table 1. The types of social enterprise values and their functions in local and regional development

\begin{tabular}{|c|c|}
\hline Types of Values & Functions \\
\hline Economic value & $\begin{array}{l}\text { - Produce goods and services } \\
\text { - Foster enterprise and competitiveness } \\
\text { - Create employment, especially for socially marginalized individuals and groups } \\
\text { - Train people and help them find jobs } \\
\text { - Facilitate economic/social development with grants (e.g., from foundations) and low- } \\
\text { interest loans (e.g., from credit unions) }\end{array}$ \\
\hline Social value & $\begin{array}{l}\text { - Supplement public sector social services and address welfare state problems with } \\
\text { solutions such as affordable childcare } \\
\text { - Foster innovative services and introduce new or improved services (to be later adopted } \\
\text { by the public sector) } \\
\text { - Provide alternative social service business models } \\
\text { - Aid recovery by providing services to those whom other initiatives cannot or do not } \\
\text { reach } \\
\text { - Foster social inclusion, social cohesion, and social capital } \\
\text { - Enhance civic involvement through volunteering }\end{array}$ \\
\hline Regional value & $\begin{array}{l}\text { - Contribute to enterprises with low levels of private entrepreneurship } \\
\text { - Create and manage workplaces } \\
\text { - Facilitate land, structure, and resource ownership for community use } \\
\text { - Provide local facilities in remote communities, such as shops and pubs } \\
\text { - Refurbish old structures to preserve local history that could otherwise be lost to } \\
\text { redevelopment } \\
\text { - Provide local public amenity spaces }\end{array}$ \\
\hline $\begin{array}{l}\text { Environmental/cult } \\
\text { ural/artistic value }\end{array}$ & $\begin{array}{l}\text { - Promote and practice environmental sustainability } \\
\text { - Implement recycling systems when financial returns to the private sector is low } \\
\text { - Facilitate artistic and sports activities }\end{array}$ \\
\hline Political value & $\begin{array}{l}\text { - Advocate for an equitable society, democratic participation, and involved citizenship } \\
\text { - Facilitate stakeholder engagement and pluralism } \\
\text { - Provide an alternative economic approach and show that business is for more than } \\
\text { maximizing profit and personal enrichment } \\
\text { - Provide an alternative model }\end{array}$ \\
\hline
\end{tabular}

Source: $(6$, p. 7$)$ 
Social entrepreneurs are regarded as the agents of change, for they make use of the instruments

of entrepreneurship in order to provide systemic solutions to social and environmental problems (13), while at the same time ensuring their own survival and sustainability (14). The main objective of the business sector organizations is to earn profit. Unlike them, social enterprises are orientated towards individual motivation and leadership and fulfill a double objective - one of both social and economic character $(15,16)$. Social enterprises perform a certain "triptych combining corporate citizenship, economic activity and democratic governance" $(17$, p. 19). It is important to point out that for their activity in the name of public good, social enterprises reinvest their profit, rather than seeking government subsidy (18). Consequently, social entrepreneurs have to find innovative solutions to the social problems in their community that have not so far been covered by the existing system (19), as it is their mission to create social value. To this end, they are often expected to develop innovative strategies for achieving the said mission (20). Achieving successful social innovation calls for bringing together market mechanisms, academic knowledge and technologies. This symbiosis will initiate new processes, services and products to benefit sustainable regional development.

Being socially orientated, social enterprises place the wellbeing of entire communities and specific territories in the centre of their business and other activities while manufacturing products and providing services that meet emerging needs (21). Typically, social enterprises activity is associated with providing social services $(19 ; 22)$. But the advent of the new requirements for sustainable development brings to the foreground the need for new projects of social enterprises that should assume the form of innovative strategies. In the process of implementation of social innovations social enterprises can collaborate with multiple other stakeholders. Their work together contributes to further expanding economic and public relationships on the particular community territory.

An additional advantage of social entrepreneurship is that such businesses usually concentrate in sectors that are not particularly profitable for private business or ones that are
BLAGOICHEVA $H$.

not sufficiently ensured by public authorities. Therefore, social innovations in social entrepreneurship are often directed at the niche sector between the market and the government that is basically about supplying goods and services through market mechanisms, but simultaneously accompanied by reinvestment to the benefit of the public $(23,24)$.

\section{THE NEED TO SUPPORT SOCIAL ENTREPRENEURSHIP}

What we have outlined so far is a picture that clearly demonstrates the benefits social entrepreneurship brings to sustainable regional development. According to some authors there exists among community leaders the belief that entrepreneurship is the defining trend of the $21^{\text {st }}$ century (9). No wonder Jeff Skoll, co-founder of eBay, created a foundation and donated $4,4 \mathrm{~m}$ GBP to set up a research centre for social entrepreneurship, while Jeff Bezos, founder of Amazon offers a million dollar award for innovative approaches and revolutionary solutions which will effectively improve communities or the world in general $(9$, p. 5).

The new understanding of sustainable regional development shifts the focus from purely economic objectives to public and social problems. This demands that a consensus be reached in relationships and collaboration in order to achieve all three goals of sustainable development. The consensus, however, is hampered when there is a multitude of stakeholders involved. Different positions are formulated owing to asymmetry of information, different knowledge levels and vested interests. In this aspect growing awareness of social values and building a network of joint activities on the part of social enterprises and other institutions within the community will have a positive impact. Expanding the network helps towards exchange of information and reducing differences of position, which in turn contributes to building sustainable regional development (25). At the same time, although social entrepreneurs are viewed as persons who cooperate in meeting social needs that have so far been unsatisfied, the academic discourse concerning how this process will evolve in reality is still scant (26).

On the basis of the study performed by Rydin and Holman (27) about the role of social capital, there can be brought forward several of the 
problems facing sustainable development and the response social entrepreneurship can provide. Barriers to sustainable development most often come as lack of participation, lack of goodwill, lack of cooperation and lack of resources. These premises seriously limit the possibilities for sustainable regional development. To respond to the said challenges social enterprises can offer various incentives for the participation of other institutions or the wide public. The well-founded and successfully popularized social goal can help persuade stakeholders and eventually result in a mutually beneficial consensus. Developing social innovations in the interest of public groups and including all stakeholders is a prerequisite for the formation of the necessary capacity for activities and experts. All of this brings about an appropriate resource allocation. Here, of course, the question remains of conflicting individual views and individual perceptions about how much the pursuit of public good will influence their own wellbeing.

The idea of the social enterprise is simple in itself - self-support and generating possibilities for overcoming social adversity or environmental problems. In reality, however, the organization of a social enterprise in itself is has to comply with a number of legal forms and norms (an enterprise, a corporation, a foundation, etc.), economic models, dimensions and interactions with business sectors and the government. The complex character of all these ties and interactions is an impediment to a realistic quantitative assessment of the activity and results in the sphere of social entrepreneurship and its absorption by the economic and political ecosystem, and beyond these - by the citizens of the region themselves (28).

Obviously, although social enterprises are not the dominant form of business management that contributes for regional economic development, they can be viewed as the principal actors within the social economy framework who can facilitate sustainable local and regional development. Their advantages stem from their abilities to combine 'in a single basket' economic, environmental and social goals, and thus help satisfy various local and regional needs.

But in order to achieve such a combination, sometimes social entrepreneurs themselves have to undergo a process where their own sustainable values clash (6). Figure 1 represents a flowchart of the actions social entrepreneurs take in cases when balance is needed between resolving local and regional issues and the entrepreneur's own social goals. Taking into consideration the three-lever mechanism of sustainable development (economic, social and environmental one), social entrepreneurs have to recognize the problem, its social implications, the possible stakeholders and the options for cooperation and coordination, so that the solution to the problem (though with a certain degree of conflict of interests) should contribute to creating sustainable value. More often than not social entrepreneurs have to focus on ambiguous needs that cannot be explained through the criteria for the nature of social enterprises but are justified by the overall criteria for regional sustainability.

Last but not least, a point should be made of the possibility for the social entrepreneurship to work together with the government and the civil society for the overcoming of certain common social challenges and social exclusion, and for seeking broader growth models. This role is even more important in a situation of budget deficits, the welfare state's limited abilities to generate wellbeing and the existing high levels of income inequality for different groups of the population.

For this reason, over the last two decades increasing attention has been observed on the part of national and European public institutions, to the activities of social entrepreneurs, the emphasis being on the social innovations they initiated. Since 2011 the European Commission has taken a number of measures to support the development of social enterprises and social entrepreneurship (29). The commission has funded over a dozen significant international research and practical projects in the field of social entrepreneurship (30). Part of the sponsored projects is characterized by a strong emphasis on the collective work of the participants from among the civil society (and social movements) in the name of social innovations (31). Market-orientated solutions have not been the object of such growing attention, as what is needed is an inclusive management, that is, a social enterprise management characterized by democratic decision-making processes. 


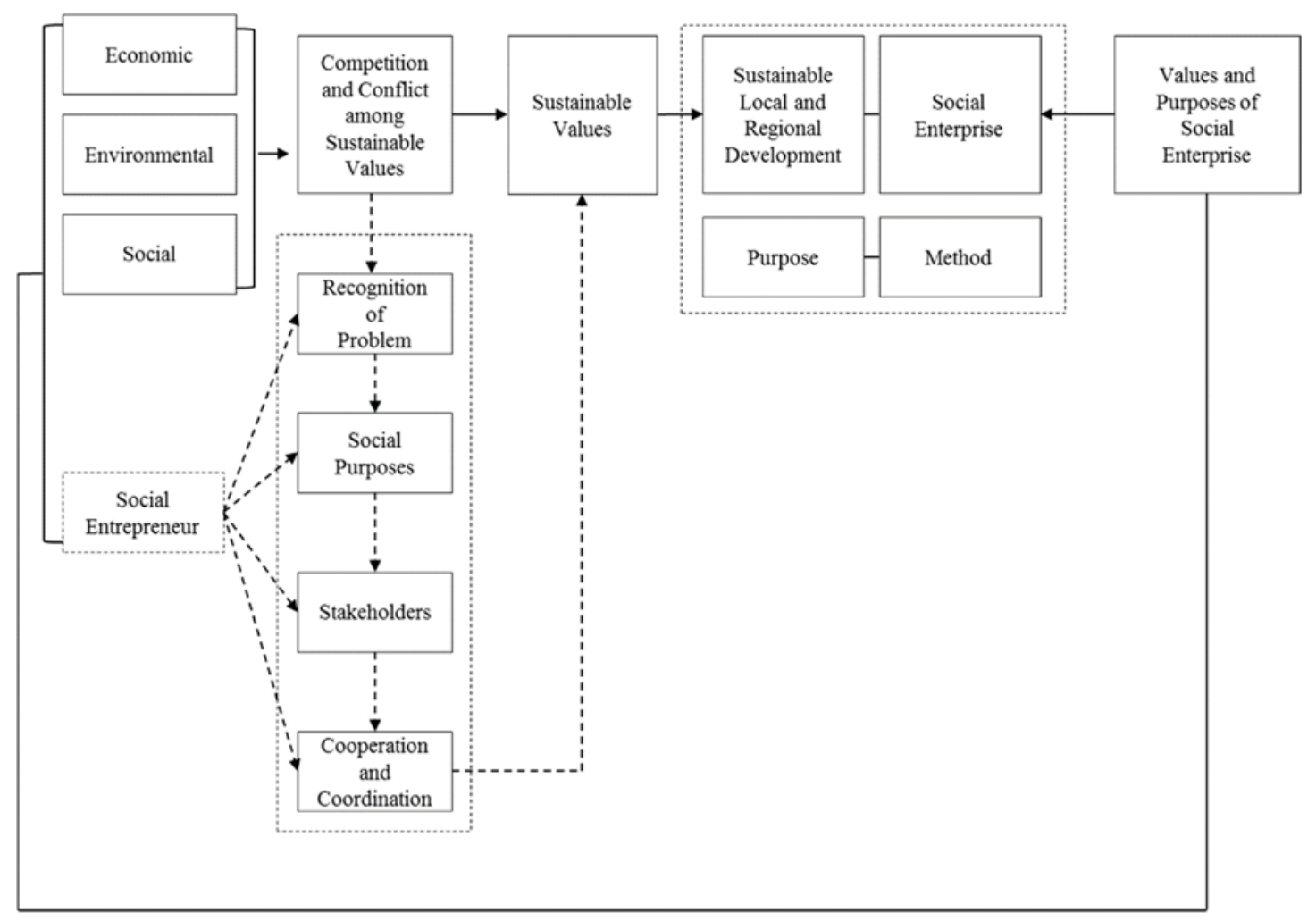

Source: (6, p. 10)

Figure 1. Sustainable values, social enterprise, and sustainable regional development

When securing support for the development of social entrepreneurship it is not enough to provide a solid foundation of projected efficiency and social results. A much stronger factor is the aspect of key points that can eventually obstruct the social impact desired. The possible barriers to consider in advance may be physical, resource-related, institutional or legal. There should be provided an opportunity for equal support for social enterprises and for small and medium-sized businesses. When the financial resource is obtained, it is necessary to forecast possible market failures throughout the various stages in the lifecycle of the social idea or the social innovation.

\section{CONCLUSION}

The social economy strategy emphasizes on the social values of the community and meeting regional needs. Within the frameworks of social economy, social enterprises have already proved their worth not only as a well-functioning category, but also as a means of firm support for sustainable regional development. This is precisely the reason why over the last years there has been observed a process of convergence of the two concepts - that of sustainable development and that of social entrepreneurship.
A major criterion for the success of sustainable development and the solution to complex problems in the community is the ability of social enterprises to generate social innovations. To implement innovative processes social enterprises are able to enter into partnerships with various stakeholders, thus joining and combining their social goals with the market objectives of the business. They can experiment with various initiatives which encourage bringing together certain groups and institutions in the region, business partnerships and even building entire local manufacturing chains, thus responding in a sustainable manner to new needs and changing situations. In this way social enterprises can assist in standing up to the economic, environmental and social challenges, while at the same time encouraging joint efforts and exchange of institutional, market or community-related resources.

Simultaneously social enterprises are facing various challenges regarding legal regulation, financial resources, asymmetry of information about their activity, and occasionally lack of understanding on the part of business and the society in general. Consequently, the support of public institutions is urgently needed when these problems are resolved. The European Union has already developed and regulated a number of policies and programs in support of 
sustainable and inclusive growth, with a strong accent on social entrepreneurship. Although there are other measures and programs yet to be developed, at present of crucial importance is the recently started initiative for social entrepreneurship.

\section{REFERENCES}

1. Brundtland, G. H., Our common future: The World Commission on Environment and Development. Oxford University Press, Oxford, 1987.

2. Hopwood, B., Mellor, M. and O'Brien, G., Sustainable development: Mapping different approaches. Sustainable Development. 13: 38-52, 2005.

3. Monzon J. L. and Chaves R., The European social economy: Concept and dimension of the third sector. Annals of Public an Cooperative Economics. 79: 549-577, 2008.

4. Rogers, P.P., Jalal, K.F. and Boyd, J.A., An Introduction to Sustainable Development, Earthscan: London, UK, 2008.

5. Marin, A., Value creation through sense making: social entrepreneurship for local sustainable development. Projectics / Proyéctica / Projectique. 3 (18): 89-106, $2017 . \quad$ Available at: https://www.cairn.info/revue-projectique2017-3-page-89.htm?contenu=resume.

6. Kim, D. and Lim, U., Social Enterprise as a Catalyst for Sustainable Local and Regional Development. Sustainability, 9 (1427): 115, 2017.

7. Beer, A., Haughton, G. and Maude, A., Developing Locally: An International Comparison of Local and Regional Economic Development, Policy Press: Bristol, UK, 2003.

8. Pike, A., Rodríguez-Pose, A. and Tomaney, J., Local and Regional Development, Routledge: London, UK, 2006.

9. Seelos, C. and Mair, J., Sustainable Development: How Social Entrepreneurs Make it Happen (October 2005). IESE Business School Working Paper No. 611, 2005. Available at SSRN: https://ssrn.com/abstract=876404 or http://dx.doi.org/10.2139/ssrn.876404.

10.Connelly, S. Mapping sustainable development as a contested concept. Local Environment: The International Journal of Justice and Sustainability. 12 (3): 259-278, 2007.

11. Picciotti, A., Towards Sustainability: The Innovation Paths of Social Enterprise. Annals of Public and Cooperative Economics. 88: 233-256, 2017.
BLAGOICHEVA $H$.

12.Seelos, C. and Mair J., Profitable business models and market creation in the context of deep poverty: A strategic view. Academy of Management Perspectives. 21: 49-63, 2007.

13.Partzsch, L. and Ziegler, R., Social entrepreneurs as change agents: A case study on power and authority in the water sector. International Environmental Agreements: Politics, Law and Economics. 11: 63-83, 2011.

14.Mair, J. and Martí, I., Social entrepreneurship research: A source of explanation, prediction, and delight. Journal of World Business. 41: 36-44, 2006.

15.Newth, J. and Woods, C., Resistance to social entrepreneurship: How context shapes innovation. Journal of Social Entrepreneurship. 5: 192-213, 2014.

16. Newth, J. Social enterprise innovation in context: Stakeholder influence through contestation. Entrepreneurship Research Journal. 6: 369-399, 2016.

17. Boussaguet, S., and Haddad, L., From Creating Value to Creating Meanings: Doing Differently. Entreprendre \& Innover. 17(1): 18-29, 2013.

18.Peattie, K. and Morely, A., Social Enterprise: Diversity and Dynamics, Contexts and Contribution-A Research Monograph, ESRC Centre for BRASS: Cardiff, UK, 2008.

19.Bacq, S. and Janssen, F., The multiple faces of social entrepreneurship. A review of definitional issues based on geographical and thematic criteria. Entrepreneurship and Regional Development. 23: 373-403, 2011.

20.Ridley-Duff, R., Seanor, P. and Bull, M., Leadership, social and ecoentrepreneurship, in R. Ridley-Duff and M. Bull. (eds.), Understanding Social Enterprise. Theory and Practice, Sage, London, pp. 203-224, 2016.

21.Defourny J., Introduction. From third sector to social enterprise, in C. Borzaga and $\mathrm{J}$. Defourny (eds.), The Emergence of Social Enterprise, Routledge, London, pp. 1-28, 2001.

22.Kerlin J.A., Defining social enterprise across different contexts: A conceptual framework based on institutional factors, Nonprofit and Voluntary Sector Quarterly. 42: 84-108, 2013.

23.Austin, J., Stevenson, H. and Wei-Skillern, J., Social and commercial entrepreneurship: Same, different, or both?. Entrepreneurship Theory and Practice. 30: 1-22, 2006. 
24.Furmanska-Maruszak, A. and Sudolska, A., Social innovations in companies and in social economy enterprises. Journal of Competition Law \& Economics. 19: 169191, 2016.

25.Dale, A. and Onyx, J.A., Dynamic Balance: Social Capital and Sustainable Community Development, University of British Columbia Press: Vancouver, BC, Canada, 2005.

26.Hall, J.K., Daneke, G.A., Lenox, M.J., Sustainable development and entrepreneurship: Past contributions and future directions. Journal of Business Venturing. 25: 439-448, 2010.

27.Rydin, Y. and Holman, N., Re-evaluating the contribution of social capital in achieving sustainable development. Local Environment. 9: 117-133, 2004.

28.MOUVES. Economic efficiency at the service of the general interest. The White Paper on Social Entrepreneurs, (2nd ed.).
BLAGOICHEVA $H$.

Paris: Rue de l'échiquier - Mouvement des entrepreneurs sociaux, 2012.

29. Communication from the Commission to the European Parliament, the Council, the European Economic and Social Committee and the Committee of the Regions. Single Market Act II Together for new growth. COM 573, 2012.

30.BEPA (Bureau of European Policy Advisers). Social Innovation, a decade of change. European Union. Luxembourg, 2014.

31.Moulaert, F., Jessop, B., Hulgård, L., and Hamdouch, A. Social Innovation: A new stage in innovation process analysis?. In: Moulaert, MacCallum, Mehmood, Hamdouch, eds. Handbook on Social innovation: Collective action, Social learning and Transdisciplinary research. Southampton: Edward Elgar, 2013. 